\title{
PENINGKATAN HASIL BELAJAR SISWA KELAS IX SMP MELALUI PENDEKATAN EDUKATIF OLEH GURU PENDIDIKAN AGAMA KRISTEN
}

\author{
Tianggur Medi Napitupulu \\ Institut Agama Kristen Negeri Tarutung
}

\begin{abstract}
This study aims to find out of the students' learning outcomes through the educational approach of Christian religious educational teachers. The population are the ninth grade students who are protestant Christian, were 189 students and the sample of this study taken from the population it can be take 25\% from 189 they were 47 students. The questionnaire trial was consist of 30 students. The data of research were analyzed using the following steps: Test the relationship obtained by the value of $r_{r x y}=0.832>r_{\text {table }}(\alpha=0.05, I K=95 \%, n=47)=0.288$, it was found that there was a significant improving of the students learning outcomes through the educational approach of Christian religious educational teachers. The significant relationship test obtained value of $t_{\text {count }}=10,074>t_{\text {table }}(\alpha / 2=0.025, d k=n-2=45)=2,021$ then it is known that there is a significant improving of the students learning outcomes through the educational approach of Christian Religious Educational teachers. Test the coefficient of determination $\left(r^{2}\right)=0.692$ and the percentage of improving in students learning outcomes through the educational approach of Christian Religious Educational Teachers is $69.2 \%$, there is a positive and significant improving students learning outcomes through the educational approach of Christian religious educational teachers.
\end{abstract}

Keywords: learning outcomes, Christian Religious Educational Teachers

\begin{abstract}
ABSTRAK
Penelitian ini bertujuan untuk mengetahui besarnya peningkatan hasil belajar melalui pendekatan edukatif guru Pendidikan Agama Kristen. Populasi penelitian adalah siswa yang beragama Kristen Protestan sebanyak 189 orang dan sampel penelitian berjumlah $189 \times 25 \%=47$ orang. Uji coba angket dilakukan kepada 30 orang siswa kelas IX SMP. Data penelitian dianalisis dengan langkah sebagai berikut:: Uji hubungan yang diperoleh nilai $\operatorname{rrxy}=0,832>\operatorname{rtabel}(\alpha=0,05, \mathrm{IK}=95 \%, \mathrm{n}=47)=$ 0,288 maka diketahui terdapat peningkatan hasil belajar siswa yang signifikan melalui pendekatan edukatif guru PAK. Uji hubungan yang signifikan diperoleh nilai thitung $=10,074>\operatorname{ttabel}(\alpha / 2=0,025, \mathrm{dk}=\mathrm{n}-2$ $=45)=2,021$ maka diketahui terdapat peningkatan hasil belajar siswa yang signifikan melalui pendekatan edukatif guru PAK. suji koefisien determinasi $\left(\mathrm{r}^{2}\right)=0,692$ dan persentase peningkatan hasil belajar melalui pendekatan edukatif guru PAK adalah $69,2 \%$, yaitu terdapat peningkatan hasil belajar yang positif dan signifikan melalui pendekatan edukatif guru pendidikan agama Kristen.
\end{abstract}

Kata Kunci: Hasil belajar, Guru Pendidikan Agama Kristen

45 Korespondensi mengenai artikel dapat dilakukan kepada: Tianggur Medi Napitupulu, Institut Agama Kristen Negeri Tarutung, Jl. Raya Tarutung-Siborong KM 11, Silangkitang, Sipoholon, Tapanuli Utara (22452), Indonesia E-mail Corresponding: tianggurnapitupulu74@yahoo.co.id 


\section{PENDAHULUAN}

Kegiatan belajar mengajar disekolah tidak terlepas dari hubungan antara guru dan anak didik. Sesuai dengan profesinya seorang guru dituntut mempunyai keahlian dalam menyampaikan pelajaran yang sesuai dengan tujuan pembelajaran.ketika semua orang mempersoalkan masalah dunia pendidikan, figur seorang guru harus terlibat dalam agenda pembicaraan terutama pendidikan formal disekolah di lingkungan sekolah tentu anak didik akan menyenangi gurunya ketika gurunya memberikan yang terbaik dalam pengajarannya, sehingga dengan demikian kualitas belajar anak pun semakin meningkat.

Kualitas anak itu dapat dilihat dari tingkat keberhasilan belajar yang diperoleh anak itu sendiri. Meningkatnya hasil belajar anak tentu dipengaruhi oleh berbagai faktor, misalnya peranan guru, kompetensi guru dan kemampuan guru dalam mengajar baik dilihat dari strategi, metode dan pendekatan yang digunakan oleh guru, sarana dan fasilitas, kondisi fisik, bakat, minat, motivasi, serta kemampuan kognitif siswa itu sendiri. Pendekatan edukatif yang dilakukan guru adalah merupakan kegiatan yang dilaksanakan secara terencana,terarah dengan partisipasi aktif. Pendekatan edukatif merupakan salah satu dari beberapa pendekatan yang dilakukan guru dalam mengajar. Pendekatan edukatif yang dilakukan guru dimaksudkan agar tercapainya tujuan pembelajaran dari mata pelajaran yang diajarkan dengan melihat hasil belajar yang dicapai siswa.

Dalam kitab Injil juga dijelaskan bahwa Yesus juga telah melakukan pendekatan edukatif yang harus ditiru oleh murid-muridNya. Ia mengatakan "sebab Aku telah memberikan suatu teladan kepada kamu, supaya kamu juga berbuat sama seperti yang telah Kuperbuat kepadamu” (Yohanes 13:15). Melalui pengamatan penulis di SMP Negeri 2 Tarutung, penulis melihat bahwa guru PAK sudah melakukan pendekatan edukatif. Hal ini dapat dilihat melalui tindakan, sikap dan perbuatan guru, PAK yang secara khusus melalui kedisiplinan guru dalam mematuhi peraturan sekolah, kepedulian guru PAK dalam menjalankan tugasnya sebagai pendidik. Dan hal inilah yang patut ditiru oleh anak didiknya dalam belajar sehingga ada perubahan yang tampak dalam diri anak didik tersebut.

Namun apabila diamati dari hasil belajar siswa masih didapati perbedaan antara siswa yang satu dengan yang lainnya. Hasil belajar siswa ini dapat dilihat ketika mereka menjawab soalsoal yang diujikan oleh guru melalui test mengenai materi pelajaran PAK yang telah dipelajari. Tentu banyak menyebabkan hasil belajar siswa itu berbeda-beda. Baik faktor dari dalam diri siswa itu sendiri, maupun dari luar. Dan faktor dari diri siswa seperti inteligensi, minat, kesehatan, bakat, dengan kata lain hal ini berkaitan dengan kemampuan siswa itu sendiri. Dan faktor dari luar seperti keluarga, masyarakat, dan juga sekolah yang dimana secara khusus guru yang berusaha untuk melakukan pola pendekatan yang edukatif. Pendekatan edukatif yang dimaksud adalah dimana guru melaksanakan secara sistematis,terencana,terarah dengan partisipasi indivifu maupun kelompok.

46 | Peningkatan Hasil Belajar Siswa Kelas IX SMP melalui Pendekatan Edukatif... Napitupulu, Tianggur Medi Jurnal Christian Humanioran | http://e-journal.iakntarutung.ac.id/index.php/humaniora 
Menurut Djamarah dan Zain (2006:59-61) pendekatan edukatif juga dapat dilakukan melalui: (1) Apapun yang guru lakukan dalam pendidikan dan pengajaran semuanya bertujuan untuk mendidik, bukan karena motif-motif lain, seperti dendam, gengsi, ingin ditakuti dan sebagainya. (2) Ketika anak didik melakukan kesalahan, maka tidak tepat diberikan sanksi hukum dengan cara memukul badannya hingga luka atau cidera. Hal ini merupakan tindakan sanksi hukum yang tidak bernilai pendidikan. (3) Dalam pendidikan, guru akan kurang arif dan bijaksana bila menggunakan kekuasaan, karena hal itu bisa merugikan pertumbuhan dan perkembangan kepribadian anak didik. (4) Guru harus dapat menjalin hubungan yang akrab kepada semua anak didik karena jikalau terdapat kerawanan hubungan komunikasi antara guru dan anak didik akan menjadi kendala dalam melakukan pendekatan edukatif. (5) Tindakan guru yang dendam, marah, kesal, benci, dan sejenisnya bukanlah termasuk perbuatan yang mendidik, karena apa yang guru lakukan itu menurutkan kata hati atau untuk memuaskan hati.

Pendekatan edukatif tampak juga dalam tindakan guru yang mendidik, hal ini sejalan dengan pendapat Hasbullah (2005:29) yang mengatakan bahwa ada beberapa bentuk tindakan guru yang mendidik, antara lain:1). Teladan, 2). Anjuran, suruhan dan perintah, 3). Larangan, 4). Pujian dan hadiah, 5). Teguran, 6). Peringatan dan ancaman, 8). Hukuman. Sementara Silitonga (2009:26-31), mengatakan terdapat beberapa tindakan-tindakan pendidikan yang telah dilaksanakan oleh Yesus dalam proses pengajaran dan pendidikanNya. Dan sebagai seorang guru Pendidikan Agama Kristen perlu meniru tindakantindakan pendidikan yang telah dilaksanakan Yesus. Tindakantindakan tersebut adalah:1). Yesus memberi teladan, 3). Yesus memberi perintah, 3). Yesus memberi larangan, 4). Yesus memberikan pujian, 5). Yesus memberi teguran, 6). Yesus memberi ancaman, 7).Yesus memberi hukuman. Menurut Furqon (2010:171172), sikap terbaik yang harus dimiliki seorang guru adalah (1) peduli, (2) menebarkan salam dan kedamaian, (3) bijak dalam berbicara, santun dalam berbuat, dan baik dalam bersikap, 4). Tidak bersikap keras, 5).

Tidak bersikap terlalu lunak dan lemah. Tirtarahardja dan La Sulo (2005 : 119) mengatakan bahwa perbutan guru yang mendidik sebagai berikut: 1). Guru sebagai teladan. Guru sebagai teladan maka peranannya adalah untuk ditiru dan dicontoh oleh siswa. Oleh karena itu guru harus menunjukan perilaku yang baik dihadapan siswanya. Salah satu contoh perilaku guru yang baik adalah berdisiplin dan bertanggung jawab. Guru berdisiplin adalah guru yang mampu mematuhi segala peraturan yang berlaku di sekolah maupun di dalam masyarakat. Guru yang bertanggung jawab adalah guru yang melaksanakan tugasnya dengan sungguhsungguh demi kepentingan siswa siswanya. 2) Guru sebagai pembangun kemauan. Guru sebagai pembangunan kemauan siswa, maka peranan guru adalah memberikan surport kepada siswanya agar belajar dengan sungguh-sungguh demi 
masa depannya. Semboyan ing madya mangun karsa (jika di tengah-tengah, membangkitkan kehendak, hasrat atau motivasi) memiliki arti bahwa seorang guru harus dapat mengupayakan untuk memperkuat motivasi pada saat situasi kurang bergairah atau ketika ragu-ragu dalam melakukan tindakan dalam belajar. Guru memberikan penguatan baik yang bersifat positif (positive reinforcement) maupun yang bersifat negatif (negative reinforcement).

Penguatan positif berupa pemberian pujian dan hadiah terhadap siswa. Siswa yang berprestasi baik diberikan hadiah sebagai penghargaan atas usahanya. Sedangkan siswa yang berperilaku baik diberikan pujian, sehingga dengan demikian pada diri siswa tertanam nilai perilaku untuk berbuat baik. Penguatan negatif berupa hukuman (punishment) ataupun pembatalan terhadap sesuatu yang telah diberikan. Bilamana siswa melakukan perilaku-perilaku yang menyimpang dalam belajar seperti menyontek, tidak mengerjakan tugas yang diberikan oleh guru perlu memberikan hukuman agar perilaku seperti itu tidak diulangi lagi. Sedangkan pembatalan adalah penarikan kembali suatu penghargaan atau keputusan yang telah diberikan kepada siswa karena mengetahui apa yang dilakukan oleh siswa tersebut ternyata tidak benar.

Hamalik (2007:159) mengemukakan bahwa: "Hasil belajar adalah keseluruhan kegiatan pengukuran dan pengolahan penafsiran dan pertimbangan untuk membuat keputusan tentang hasil belajar yang dicapai oleh siswa setelah melakukan kegiatan belajar dalam upaya mencapai tujuan pembelajaran yang ditetapkan." Ada beberapa alat yang digunakan guru untuk mengetahui hasil belajar yang dicapai oleh siswa. Menurut Djamarah (2010:120) hasil belajar dapat diketahui melalui:1). Test, 2). Observasi, 3). Memperhatikan pekerjaan siswa, 4). Interviu. Menurut Sudjana (2010:35) bahwa alat-alat penilaian hasil belajar yakni tes, baik tes uraian (esai) dan tes objektif.

Sedangkan menurut Hamalik (2007:166) bahwa: "Alat untuk mengetahui hasil belajar siswa adalah dari penilaian dengan tes dan penilaian bukan tes". Hasil belajar siswa di sekolah 70 persen dipengaruhi oleh kemampuan siswa dan 30 persen dipengaruhi oleh lingkungan. Disamping faktor kemampuan yang dimiliki siswa, faktor lingkungan yang mempengaruhi hasil belajar siswa seperti motivasi belajar, minat dan perhatian, sikap dan kebiasaan belajar, ketekunan, social, ekonomi, dan faktor fisik dan psikis. Sementara Caroll, seperti yang dikutip oleh Sabri (2010:46) berpendapat hasil belajar siswa dipengaruhi oleh lima faktor, yakni :1).Bakat pelajar, 2). Waktu yang tersedia untuk belajar, 3). Waktu yang diperlukan siswa untuk menjelaskan pelajaran, 4). Kualiatas pengajaran, 5). Kemampuan individu. Hasil belajar yang dicapai oleh siswa dipengaruhi oleh banyak faktor, salah satunya adalah faktor pendekatan yang dilakukan oleh guru kepada siswa.

Dalam merancang kegiatan pembelajaran, guru terlebih dahulu memahami karakteristik siswa, tujuan pembelajaran yang ingin dicapai oleh siswa, materi ajar 
yang akan disajikan, dan cara yang digunakan oleh guru untuk mengemas penyajian materi serta bentuk penilaian yang akan digunakan guru dalam mengukur ketercapaian tujuan pembelajaran. Mulyasa (2009:95) bahwa: "Pendekatan dan metode pembelajaran yang dipilih dan digunakan oleh guru dalam melaksanakan pembelajaran secara efektif berupaya meningkatkan hasil pembelajaran".

Dan menurut Syah (2010:136) mengemukakan bahwa "Disamping faktorfaktor internal dan eksternal siswa, faktor pendekatan belajar juga berpengaruh terhadap taraf keberhasilan proses pembelajaran siswa". Oleh sebab itu, guru harus aktif mengusahakan suasana yang baik itu dengan berbagai cara, baik dengan penggunaan metode mengajar yang sesuai, maupun penyediaan alat belajar yang cukup, serta pengaturan organisasi kelas yang mantap, ataupun pendekatan lainnya yang diperlukan".

Dengan demikian tindakan, perbuatan dan sikap guru dalam mendidik turut memberi sumbangan terhadap hasil belajar siswa. Sehingga lebih rinci lagi, pendekatan edukatif yang dilakukan guru sebagai pendidik yang dapat berkontribusi terhadap hasil belajar siswa dapat dilihat melalui: pertama, Guru memberi teladan kepada siswa melalui kedisiplinan guru dan perilaku bertanggung jawabnya di sekolah. Kedua, memberi perintah, anjuran dan suruhan kepada siswa tidak boleh karena motif lain seperti dendam, gengsi atau supaya ditakuti oleh siswa. Ketiga, dalam melarang siswa, guru boleh melakukannya dengan cara mendekatinya dengan perkataan ataupun memukulnya dengan batas yang wajar.

Keempat, memberi hadiah dan pujian di saat siswa berhasil dalam belajarnya. Kelima, memberi teguran kepada siswa ketika siswa salah dengan tidak menyakiti perasaan siswa. Keenam, memberi peringatan disertai dengan ancaman yaitu berupa sanksi yang diterima siswanya. Ketujuh, dalam memberi hukuman, guru PAK tidak boleh memukul siswa sampai cidera. Kedelapan, Guru memberi penguatan kepada siswa untuk membangun kemauan siswanya. Kesembilan, guru mengarahkan siswanya supaya tidak menyimpang dari aturanaturan sekolah.

\section{METODE}

Metode penelitian yang digunakan adalah metode penelitian kuantitatif.Penelitian ini dilakukan di SMP Negeri 2 Tarutung kabupaten Tapanuli Utara.Populasi dalam penelitian ini adalah seluruh siswa yang beragama Kristen kelas IX SMP Negeri 2 Tarutung Tahun Pembelajaran 2018/2019. Sampel dalam penelitian ini dengan mengambil $25 \%$ dari keseluruhan jumlah siswa kelas IX, sampelnya sebanyak 47 orang. Uji coba dilakukan kepada siswa kelas IX SMP Negeri 2Tarutung kabupaten Tapanuli Utara sebanyak 30 orang. Sebelum uji

49 | Peningkatan Hasil Belajar Siswa Kelas IX SMP melalui Pendekatan Edukatif... Napitupulu, Tianggur Medi Jurnal Christian Humanioran | http://e-journal.iakntarutung.ac.id/index.php/humaniora 
reliabilitas angket dilakukan, perlu dicari terlebih dahulu varians setiap butir itemnya dengan menggunakan rumus yang dikemukakanArikunto (2010:227):

$$
\sigma b^{2}=\frac{\sum x^{2}-\frac{\left(\sum x^{2}\right)}{N}}{N}
$$

Data untuk uji reliabilitas dilakukan dengan menggunakan rumus Formula Alpha Cronbach, Arikunto (2010:239) yaitu:

$$
r_{11}=\left(\frac{k}{k-1}\right)\left(1-\frac{\sum \sigma_{b}^{2}}{\sigma_{t}^{2}}\right)
$$

Untuk menghitung validitas butir soal (item) digunakan rumus koefisien korelasi biserial Arikunto (2010: 326) sebagai berikut:

$$
r_{p b i s}=\frac{M_{\rho}-M_{t}}{S_{t}} \sqrt{\frac{P}{q}}
$$

Untuk menghitung reabilitas tes dapat dihitung dengan menggunakan rumus K-R 20, Arikunto (2012: 115) :

$$
r_{11}=\left[\frac{n}{n-1}\right]\left[\frac{S^{2}-\Sigma p q}{S^{2}}\right]
$$

Rumus untuk menghitung varians total adalah:

$$
S^{2}=\frac{\sum X^{2}-\frac{\left(\sum X\right)^{2}}{N}}{N}
$$

\section{HASIL DAN PEMBAHASAN}

Dari pendistribusian hasil jawaban siswa tentang Pendekatan Edukatif Guru PAK diketahui bahwa item yang memperoleh nilai tertinggi adalah item nomor 16 dengan skor 130 dan rata-rata 2,72 yaitu banyak siswa menjawab bahwa Guru PAK memberi sanksi kepada siswa yang tidak mengerjakan PR. Sementara nilai bobot terendah dari item yang lain adalah nomor 30 dengan skor 98 dan rata-rata 2,09 yaitu masih ada beberapa siswa yang menjawab bahwa guru PAK masih kadang-kadang menerima pendapat siswa ketika siswa mengemukakan pendapatnya mengenai materi pelajaran PAK. Dari pendistribusian hasil jawaban siswa mengenai penguasaan materi pelajaran PAK yang di ukur sebagai hasil belajar siswa, maka dapat diketahui bahwa dari 47 siswa terdapat 3 orang $(6,38 \%)$ memiliki skor 59-64, 3 orang $(6,38 \%)$ memiliki skor $65-69,6$ orang $(12,76 \%)$ memiliki skor $70-74,4$ orang $(8,51 \%)$ memiliki skor $75-79,8$ orang $(17,02 \%)$ memiliki skor 80-84, 23 orang $(48,93 \%)$ memiliki skor $85-90$. Dan nilai rata-rata yang diperoleh siswa yaitu 78,55 termasuk pada kategori cukup.

Dari uji persyaratan analisis yaitu menguji apakah ada hubungan yang positif antara variabel $\mathrm{X}$ dengan variabel $\mathrm{Y}$, diperoleh nilai $\mathrm{r}_{\text {hitung }}=0,832$ dibandingkan dengan nilai $r_{\text {tabel }}$ untuk kesalahan 5\% dan interval kepercayaan (IK) $=100 \%-5 \%=95 \%$ dan untuk $N=47$ yaitu 0,288 . Diperoleh perbandingan $r_{\text {hitung }}>$ $\mathrm{r}_{\text {tabel}}$, yaitu $0,832>0,288$. Dengan demikian diketahui bahwa terdapat peningkatan 
hasil belajar melalui pendekatan edukatif guru PAK siswa Kelas IX SMP Negeri 2 Tarutung kabupaten Tapanuli Utara Tahun Pembelajaran 2018/2019.

Dari uji persyaratan analisis yaitu menguji apakah ada hubungan yang signifikan antara variabel $\mathrm{X}$ dengan variabel $\mathrm{Y}$, diperoleh nilai $\mathrm{t}_{\text {hitung }} 10,074$ dibandingkan dengan nilai $t_{\text {tabel }}$ untuk kesalahan $\alpha / 2=0,05 / 2=0,025$ dan $n-2=$ 47-2 = 45 yaitu 2,021 dengan demikian dapat diketahui bahwa terdapat kontribusi yang signifikan antara variabel $\mathrm{X}$ dengan variabel $\mathrm{Y}$ yaitu terdapat peningkatan hasil belajar yang signifikan melalui pendekatan edukatif guru PAK siswa Kelas IX SMP Negeri 2 Tarutung Kabupaten Tapanuli Utara Tahun Pembelajaran 2018/2019. Dari uji koefisien determinasi $\left(r^{2}\right)$ diperoleh $r^{2}=0,692$ dari nilai ini dapat diketahui persentasepeningkatan hasil belajar yang signifikan melalui pendekatan edukatif guru PAK siswa Kelas IX SMP Negeri 2 Tarutung Kabupaten Tapanuli Utara Tahun Pembelajaran 2018/2019 adalah: $\left(\mathrm{r}^{2}\right) \times 100 \%=$ $0,692 \times 100 \%=69,2 \%$. Dengan demikian dapat diketahui persentase peningkatan hasil belajar yang signifikan melalui pendekatan edukatif guru PAK Siswa Kelas IX SMP Negeri 2 Tarutung Kabupaten Tapanuli Utara Tahun Pembelajaran 2018/2019 adalah 69,2\% sementara 30,8\% dipengaruhi oleh faktor lain sebagaimana yang diuraikan pada identifikasi masalah yaitu faktor dari dalam diri siswa seperti kesehatan, inteligensi dan bakat, minat dan motivasi, cara belajar. Dan faktor dari luar diri siswa seperti keluarga, masyarakat dan lingkungan sekitar.

Berdasarkan uji hipotesa yang dilihat dari kriteria penolakan dan penerimaan hipotesa diperoleh nilai $\mathrm{r}^{2}>0$ yaitu 69,2>0 maka $\mathrm{H}_{0}$ menyatakan tidak ada peningkatan ditolak dan $\mathrm{H}_{\mathrm{a}}$ menyatakan ada peningkatan diterima. Dengan demikian maka dapat diketahui bahwa hipotesa penelitian yang diajukan oleh penulis diterima yaitu terdapat peningkatan hasil belajar siswa yang positif dan signifikan melalui pendekatan edukatif guru PAK Siswa Kelas IX SMP Negeri 2 Tarutung Kabupaten Tapanuli Utara Tahun Pembelajaran 2018/2019.

\section{PENUTUP}

Terdapat hubungan yang positif dan signifikan antara peningkatan hasil belajar melalui pendekatan edukatif guru PAKKelas IX SMP Negeri 2Tarutung Kabupaten tapanuli Utara T.P 2018/2019, karena dari uji persyaratan analisis

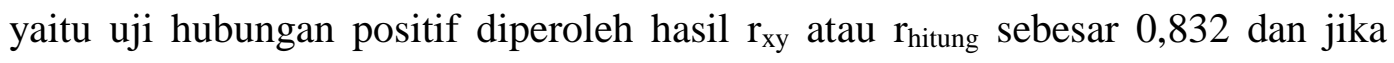
dibandingkan dengan nilai $r_{\text {tabel }}$ pada sampel 47 orang dan interval kepercayaan 95\% diperoleh harga $r_{\text {tabel }} 0,288$ artinya $r_{\text {hitung }}$ lebih besar dari $r_{\text {tabel }}$, maka hal ini menyatakan bahwa terdapat hubungan yang positif dan signifikan peningkatan hasil belajar siswa melalui pendekatan edukatif guru PAK. Dan juga dari uji persyaratan analisis yaitu uji hubungan signifikan diperoleh $t_{\text {hitung }}$ sebesar 10,074 dan jika dibandingkan dengan nilai $t_{\text {tabel }}$ untuk kesalahan $\alpha / 2=5 \% / 2=0,025$ uji dua pihak dan $\mathrm{dk}=\mathrm{n}-2=47-2=45$, maka diperoleh $\mathrm{t}_{\text {tabel }}=2,021$ artinya $\mathrm{t}_{\text {hitung }}$ lebih 
besar dari $t_{\text {tabel }}$ yaitu 10,074 > 2,021 maka hal ini menyatakan bahwa terdapat hubungan yang signifikan peningkatan hasil belajar melalui Pendekatan Edukatif Guru PAK.Peningkatan hasil belajar melalui pendekatan edukatif guru PAK siswa kelas IX adalah 69,2 \% di SMP Negeri 2 Tarutung Kabupaten Tapanuli Utara Tahun Pembelajaran 2018/2019.

\section{DAFTAR PUSTAKA}

Arikunto, S. 2010. Prosedur Penelitian Suatu Pendekatan Praktik. Jakarta: Rineka Cipta. 2012. Dasar-Dasar Evaluasi Pendidikan. Jakarta: Bumi Aksara.

Djmarah, S. B. 2010. Guru dan Anak Didik dalam Interaksi Edukatif. Jakarta: Rineka Cipta.

Furqon, H. 2010. Guru Sejati: Membangun Insan Berkarakter Kuat dan Cerdas. Surakarta: Yuma Pustaka.

Hamalik, O. 2007. Kurikulum dan Pembelajaran. Jakarta: Bumi Aksara.

Handari, Nanawi. 1981. Administrasi Pendidikan. Jakarta: Rineka Cipta.

Hasbullah. 2005. Dasar-Dasar Ilmu Pendidikan. Jakarta: PT. RajaGrafindo Persada.

Mulyasa, E. 2009.Menjadi Guru Profesional. Bandung: Rosda Karya.

Sabri, A. 2010. Strategi Belajar Mengajar dan Micro Teaching. Ciputat: quantum teaching.

Sidjabat, B.S. 2009. Mengajar Secara Profesional. Bandung: Yayasan Kalam Hidup.

Silitonga, S. 2009. Nilai-Nilai Kependidikan Dari Yesus Dan Sistem Pendidikan Nasional: Suatu Disain Teologi Kependidikan.

Soetjipto dan Raflis Kosasi. 2009. Profesi Keguruan. Jakarta: Rineka Cipta.

Suryanto dan Asep Djihad.2013. Bagaimana Calon Guru dan Guru Profesional. Yogyakarta: multi pressindo.

Syah, M. 2010. Psikologi Pendidikan Dengan Pendekatan Baru. Bandung: PT. Remaja Rosdakarya.

Tirtarahardja, U. \& Sulo, L. 2005. Pengantar Pendidikan. Jakarta: PT. Rineka Cipta. 